\title{
Metoclopramide-induced facial and palatopharyngeal myoclonus
}

回的

Supplemental data at Neurology.org
A 61-year-old woman developed acute dyslalia, dysphonia, dysphagia, and facial rhythmic jerks 8 hours after the intake of 2 tablets of metoclopramide $10 \mathrm{mg}$, prescribed for nausea during respiratory infection. Examination revealed dysphonia, dyslalia, dysphagia, and myoclonus in the orbicularis oculi (video 1 on the Neurology ${ }^{\circledR}$ Web site at Neurology.org), orbicularis oris, and palatopharyngeal (video 2); no clicking was audible. Brain MRI, angio-MRI, and EEG were unremarkable. Biperidene $4 \mathrm{mg}$ was given per os: palatopharyngeal myoclonus, dysphonia, and dyslalia improved in 30 minutes and disappeared in 12 hours. Palatal myoclonus may be a rare metoclopramide-induced movement disorder. ${ }^{1,2}$

Paolo Immovilli, MD, Eugenia Rota, MD, Nicola Morelli, MD, Ilaria Iafelice, MD, Andrea Magnacavallo, MD, Donata Guidetti, $M D$

From Guglielmo da Saliceto Hospital, Piacenza, Italy.

Author contributions: Paolo Immovilli: drafting/revising the manuscript, study concept or design, analysis or interpretation of data, accepts responsibility for conduct of research and final approval, acquisition of data, study supervision. Eugenia Rota: drafting/revising the manuscript, accepts responsibility for conduct of research and final approval. Nicola Morelli: drafting/revising the manuscript, accepts responsibility for conduct of research and final approval, acquisition of data. Ilaria Iafelice: study concept or design, accepts responsibility for conduct of research and final approval, acquisition of data. Andrea Magnacavallo: drafting/revising the manuscript, accepts responsibility for conduct of research and final approval, acquisition of data. Donata Guidetti: drafting/revising the manuscript, accepts responsibility for conduct of research and final approval.

Study funding: No targeted funding reported.

Disclosure: The authors report no disclosures relevant to the manuscript. Go to Neurology.org for full disclosures.

Correspondence to Dr. Immovilli: pimmovilli@libero.it

1. Lu CS, Chu NS. Acute dystonic reaction with asterixis and myoclonus following metoclopramide therapy. J Neurol Neurosurg Psychiatry 1988;51:1002-1003.

2. Nampiaparampil D, Oruc NE. Metodopramide-induced palatopharyngeal myoclonus. Mov Disord 2006;21:2028-2029. 


\title{
Neurology
}

\author{
Metoclopramide-induced facial and palatopharyngeal myoclonus \\ Paolo Immovilli, Eugenia Rota, Nicola Morelli, et al. \\ Neurology 2015;84;1284 \\ DOI 10.1212/WNL.0000000000001393
}

This information is current as of March 23, 2015

\begin{tabular}{|c|c|}
\hline $\begin{array}{l}\text { Updated Information \& } \\
\text { Services }\end{array}$ & $\begin{array}{l}\text { including high resolution figures, can be found at: } \\
\text { http://n.neurology.org/content/84/12/1284.full }\end{array}$ \\
\hline Supplementary Material & $\begin{array}{l}\text { Supplementary material can be found at: } \\
\text { http://n.neurology.org/content/suppl/2015/03/21/WNL.0000000000001 } \\
\text { 393.DC1 }\end{array}$ \\
\hline References & $\begin{array}{l}\text { This article cites } 2 \text { articles, } 1 \text { of which you can access for free at: } \\
\text { http://n.neurology.org/content/84/12/1284.full\#ref-list-1 }\end{array}$ \\
\hline Subspecialty Collections & $\begin{array}{l}\text { This article, along with others on similar topics, appears in the } \\
\text { following collection(s): } \\
\text { Clinical neurology examination } \\
\text { http://n.neurology.org/cgi/collection/clinical_neurology_examination } \\
\text { Myoclonus } \\
\text { http://n.neurology.org/cgi/collection/myoclonus }\end{array}$ \\
\hline Permissions \& Licensing & $\begin{array}{l}\text { Information about reproducing this article in parts (figures,tables) or in } \\
\text { its entirety can be found online at: } \\
\text { http://www.neurology.org/about/about_the_journal\#permissions }\end{array}$ \\
\hline Reprints & $\begin{array}{l}\text { Information about ordering reprints can be found online: } \\
\text { http://n.neurology.org/subscribers/advertise }\end{array}$ \\
\hline
\end{tabular}

Neurology ${ }^{\circledR}$ is the official journal of the American Academy of Neurology. Published continuously since 1951, it is now a weekly with 48 issues per year. Copyright (C 2015 American Academy of Neurology. All rights reserved. Print ISSN: 0028-3878. Online ISSN: 1526-632X.

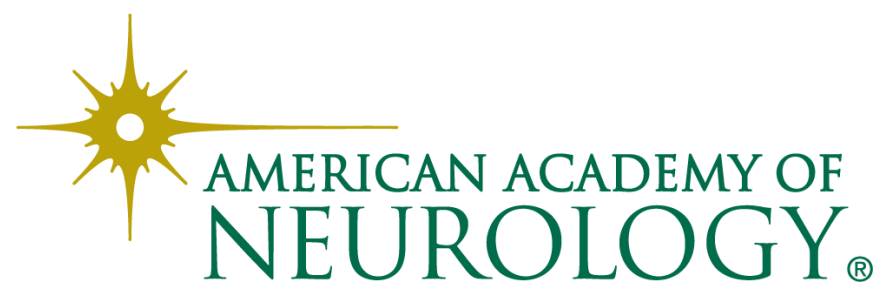

